\title{
A STRUCTURAL MODEL OF THE INFORMATION SYSTEMS PROFESSIONAL
}

\author{
Comparing practitioners, employers, students, and academics
}

\author{
Rodney Turner, Glenn Lowry and Julie Fisher \\ Victoria University, Australia; College of Business and Economics, United Arab Emirates \\ University; and Monash University, Australia. \\ Rod.Turner@vu.edu.au g.lowry@uaeu.ac.aejulie.fisher@sims.monash.edu.au
}

Abstract: This paper reports the identification and modelling of four latent variables in
the makeup of the professional repertoire of information systems
professionals. The relative importance of work experience, soft skills, IS
education, and non-IS education to four stakeholder groups, IS employers,
professionals, students, and academics, is graphically and quantitatively
represented through a second-order structural equation model. The model is
simultaneously tested against the four stakeholder groups, the fit measures are
the same for each of them, providing a commensurate basis for comparison.
The fit measure values indicate an excellent fit, within accepted limits. The
model provides a quantitative basis for identification of the relative importance
of the respective variables to the education and career development of IS
professionals. The model also includes features of the working environment
which may influence the career choices and progress of IS graduates. Analysis
of the shifts in importance attached to latent variables between groups may
provide improved understanding of changing values and perceptions of IS
professionals as careers develop and as individuals change stakeholder group
membership.

Key words: Information Systems, IS professional, IS graduates, technical skills, soft skills, hard skills, structural model. 


\section{INTRODUCTION}

The preparation, quality, and expectations of new information systems (IS) graduates continues to be the focus of many discussions, conferences, workshops, and publications by IS practitioners, employers, students, and academics.

Employers and experienced practitioners are often critical of a lack of practical experience or unrealistic views and expectations perceived to be held by some new graduates. Students and new graduates necessarily lack real world work experience, yet they sometimes have unrealistically high expectations about their immediate value. Academics continually revise curricula to accommodate change and growth in the body of knowledge and the skills that they believe are needed by students preparing for entry into professional IS roles.

How do the perceptions and needs of stakeholders change as careers develop and mature? What are the "essential" bodies of knowledge, skills, and personal characteristics that are essential for successful IS professional work? How do the relative importance of work experience, soft skills, IS education, and non-IS education differ across different groups.

\section{PREVIOUS STUDIES}

Numerous studies of the skill requirements of IS graduates, including soft skills, hard skills, and job features that help motivate IS professionals are available. (Van Slyke, Kittner et al, 1997; Young (1996).

Some compare various stakeholders such as academics and industry, or student perceptions. In the main, these studies are descriptive in nature covering curriculum emphasis, importance of skills rated in order of importance (Williams, 1998; Wong, 1996; Orr, 2000; Lee \& Koh, 2002; Goles, 2001; Farwell, Lee et al, 1993, 1995).

Interpersonal skills and technical skills are recognised as possessing equal importance for IS professionals. (Young \& Keen, 1997) IS students must develop "soft" skills and abilities in various areas including teamwork, creativity and communication.

Determining those skills employers of new IS graduates seek is important for educators in designing curricula and advising students. Van Slyke (1997) found that specific technical skills were less important than basic technical skills and non-academic skills.

Doke and Williams (1999), in a study across various IS job classifications, found that systems development skills and interpersonal 
skills were common across classifications but programming skills were more important for entry level IS positions.

Core curriculum requirements have been set in association with professional bodies in Australia (Underwood, 1997) and the USA (Gorgone, Feinstein et al, 1997). However, it has been suggested that course requirements surrounding the IS 2002 model curriculum (ACM-AIS, 2002) as it stands probably contains more technical material than can be covered in an undergraduate degree program (Beachboard \& Parker, 2003).

Yet as Ross \& Ruhleder (1993) note IS education often is seen as concentrating too much on a narrow set of technical skills and suggest that the IS curriculum should concentrate on developing technical \& business skills. Others (Ashley \& Padgett, 1997; Turner \& Lowry, 2001) have shown that despite the call from IS employers for more business orientated skills in graduating IS students, core business subjects do not rate highly.

Technical skills are not the total answer in preparing IS professional (Ross \& Ruhleder, 1993). They suggest that programs aimed at developing IS professionals of the future must cover a wide range of skills and assist the integration of these skills in complex environments. Little, Granger et al, (1999) suggest that it is not sufficient for IS graduates to just possess technical capabilities but should be aware of the need for professionals to take responsibility for their work and the importance of appropriate ethical behaviours. They further suggest a need to include these aspects in the curriculum of current IS programmes. They identify an "industry-academic gap" that leads to dissatisfaction amongst employer groups with IS graduates (Little, Granger et al, 1999).

It is indicated above that there is an interaction between the competing aspects in the development and education of IS graduates. How can these interactions be measured? The purpose of this paper is to present the results of a study utilising structural equation modelling methods to develop and validate a model that illustrates the possible relationships between these areas and the emphasis that students and IS decision makers place on them.

\section{METHOD}

A multipart questionnaire was developed to solicit the views of four different groups of stakeholders regarding the importance of academic and useful adjunct skills and abilities areas included in information systems degree programs. Drawing on previous surveys (Cheney, 1988; Cappel, 2001/2002; Farwell, Lee et al, 1995; Leitheiser, 1992; Leonard, 1999; Snoke \& Underwood, 1998a, 1998b; Tang, Lee et al, 2001; Van Slyke, Kittner et 
al, 1997; Trauth, Farwell et al, 1993) the instrument developed for this study included some additional items in the area of job features and conditions. Items were organised into several sections: demographic data, IS and business computing related skills, non-IS academic subjects, soft skills and personal characteristics, and workplace conditions and incentives.

Four variations of the instrument were developed and administered to the four stakeholder groups as follows:

1. Students were senior undergraduate information systems students in three universities in Victoria, Australia. Of a total of 300 surveys distributed to students during regular classes, 254 usable responses were received, a response rate of 84.6 percent.

2. Academics were those teaching IS subjects at Australasian universities were invited to participate by email containing a hotlink to the on-line form. A total of 396 emails were sent and 195 responded with usable replies, a response rate of 49.2 percent.

3. IS Practitioners were employed in an IS/IT capacity in Australia. One thousand two hundred questionnaires were delivered by email. A total of 136 usable responses were returned, a response rate of 11.3 percent.

4. IS managers and decision makers were those in a supervisory or managerial role responsible. One thousand seven hundred and eighty questionnaires were distributed by email. The response for this survey resulted in 153 returns with 138 usable, a 7.7 percent response rate.

\section{ANALYSIS}

\subsection{Factor Analysis}

Nine different factors were identified through exploratory factor analysis using PCA analysis with Varimax rotation. Two items were concerned with the IS job and its features, two were concerned with soft skills and personal qualities and five were concerned with educational matters from IS technical areas (three items) and non-IS academic areas (two items).

Questions that did not clearly load onto a single factor or did not have a value of at least 0.5 were excised from analysis. Item reliability was tested using Cronbach's $\alpha$. Item reliability was good with the overall value for each subscale exceeding recognised benchmark value of 0.7 (Cronbach, 1951).

Summated scales were computed using a weighted mean approach (Holmes-Smith \& Rowe, 1994; Hair, Anderson et al, 1998) where the mean scores are multiplied by their respective factor loadings, summed, and divided by the sum of the factor loadings. This procedure ensures that the 
factor loadings are properly and fully taken into account when computing the summated scales.

As a result, nine separate factors in four separate areas of interest were identified. Two factors SF1W and SF2W were identified as soft skills and these were measured by eight questions. Two factors WF1W and WF2W concerned work related incentives and these were measured by seven questions. Two factors OAF1W and OAF2W measured by eight questions were identified as non-IS academic subject areas and three factors F1W, F2W and F3W were identified as IS academic subjects, measured by eight questions. An interpretation of these factors is given in Table 1 below.

\begin{tabular}{|l|l|l|}
\hline Factor & Interpretation & Emphasis \\
\hline F1W & IS academic subjects & High level applications \\
\hline F2W & IS academic subjects & Design and development \\
\hline F3W & IS academic subjects & Web related applications \\
\hline OAF1W & Non-IS academic subjects & $\begin{array}{l}\text { Inwardly focussed core non-IS } \\
\text { business subjects }\end{array}$ \\
\hline OAF2W & Non-IS academic subjects & Outwardly orientated non-IS subjects \\
\hline SF1W & Soft skills & $\begin{array}{l}\text { Get on with people, communicate or } \\
\text { stand-out }\end{array}$ \\
\hline SF2W & Soft skills & Skills acquisition and able to do job \\
\hline WF1W & Work related incentive & Environmental and comfort \\
\hline WF2W & Work related incentive & Reward related (hygiene) factors \\
\hline
\end{tabular}

Table 1: Factor Interpretations

\subsection{Structural Modelling}

The model was developed using AMOS R5. The structural model has four latent variables. These are soft skills referring to soft skills such as interpersonal skills and team work; IS ed referring to the IS education skills outcomes and technical skills such as web development, analysis and design; non-IS ed referring to non-academic subjects such as accounting, economics and commercial law, and finally work aspects referring to aspects of the IS/IT work environment that may influence the professional. The dependent variable, IS Professional, is the combination of soft skills, education and work environment.

Appropriateness of the model structure has been discussed elsewhere (Turner, Fisher \& Lowry, 2004) and validated against independent groups. A group model was tested against sets of independent data from four stakeholder groups: students, academics IS decision makers and IS 
managers. The values of the relative importance between latent variables expressed by the four stakeholder groups are shown below.

The fit parameters for the model in Figure 1 indicate an excellent fit and are within the acceptable levels (Schumaker 2004). As the model is being simultaneously tested against four groups, the fit measures are the same. The model fit values for the four stakeholder groups are: GFI $=0.964$, AGFI $=0.934$, TLI $=0.974$, RMSEA $=0.018$ (range LO90 $=0.00, \mathrm{HI} 90=0.028$ ), $\mathrm{RMR}=0.027, \mathrm{p}=0.051$ and $\mathrm{CMIN}$ (discrep) $=1.24$. These values all indicate the model fit is sound. Standardized residual covariance values between indicators are each below the critical value suggest by Hair, Anderson et al, (1998) of 2.58 supporting the fit of the model to the data.

With the exception of the path WF1W<---work_aspects which is not significant, each of the regression weights is significant at $p<0.001$. Table 2 shows the standardised regression coefficients determined for the model. These standardized regression coefficients are significant at $p<0.001$ with critical ratios great than 2 .

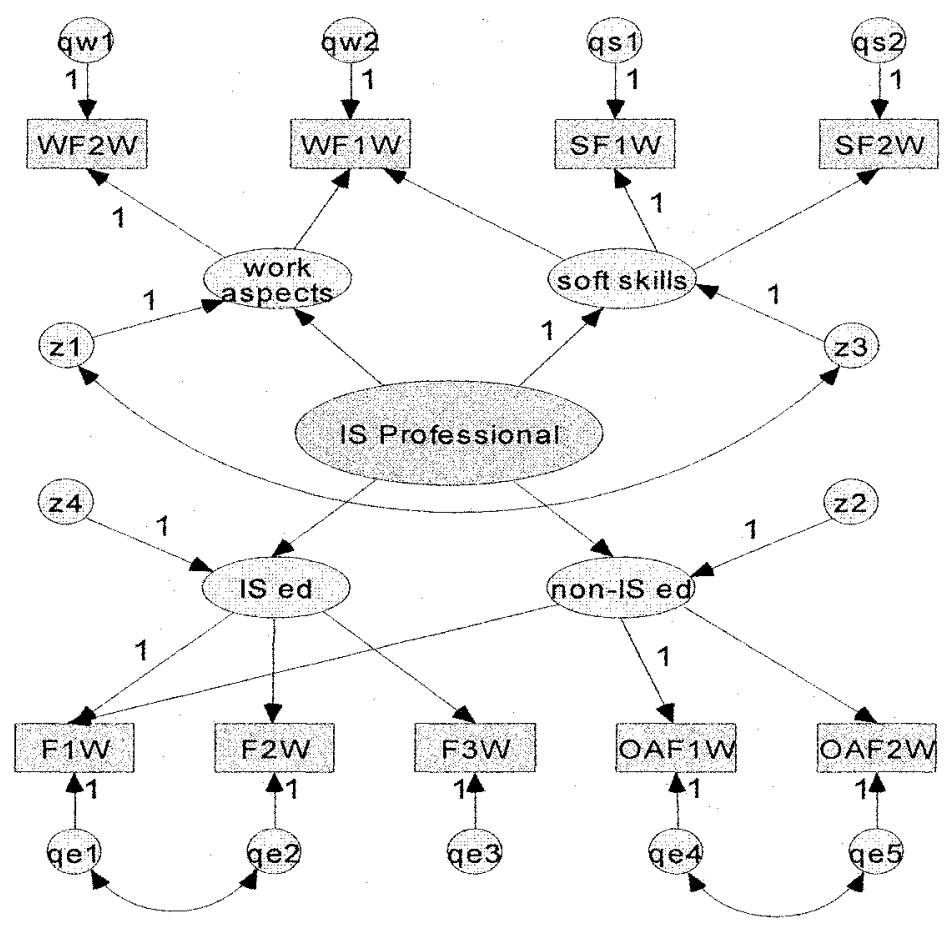

Figure 1: Model Path Diagram 
Standardized Regression Weights

\begin{tabular}{|c|c|c|c|c|c|c|}
\hline \multicolumn{3}{|c|}{ Path } & Students & Academics & $\begin{array}{c}\text { IS } \\
\text { Practitioner }\end{array}$ & $\begin{array}{c}\text { IS Decision } \\
\text { Makers }\end{array}$ \\
\hline non-IS ed & $<--$ & IS Professional & 0.96 & 0.76 & 0.96 & 0.72 \\
\hline IS ed & $<--$ & IS Professional & 0.85 & 0.82 & 0.32 & 0.70 \\
\hline soft skills & $<--$ & IS Professional & 0.88 & 0.82 & 0.85 & 0.76 \\
\hline work_aspects & $<--$ & IS Professional & 0.87 & 0.57 & 0.42 & 0.61 \\
\hline SF2W & $<--$ & soft skills & 0.63 & 0.55 & 0.61 & 0.54 \\
\hline F1W & $<--$ & is ed & 0.32 & 0.38 & 0.48 & 0.43 \\
\hline F3W & $<-$ & IS ed & 0.56 & 0.67 & 0.70 & 0.73 \\
\hline OAF2W & $<--$ & non-IS ed & 0.63 & 0.60 & 0.57 & 0.78 \\
\hline SF1W & $<--$ & soft skills & 0.72 & 0.65 & 0.76 & 0.62 \\
\hline F2W & $<--$ & IS ed & 0.53 & 0.54 & 0.66 & 0.64 \\
\hline OAF1W & $<--$ & non-IS ed & 0.46 & 0.48 & 0.42 & 0.62 \\
\hline WF1W & $<--$ & work_aspects & 0.02 & 0.08 & 0.08 & 0.10 \\
\hline WF2W & $<--$ & work_aspects & 0.61 & 0.84 & 0.75 & 0.98 \\
\hline F1W & $<\ldots$ & non-IS ed & 0.33 & 0.33 & 0.32 & 0.38 \\
\hline WF1W & $<--$ & soft skills & 0.57 & 0.40 & 0.49 & 0.43 \\
\hline
\end{tabular}

Table 2: Standardized Regression Weights

Regression weight values below 0.3 are weak, between 0.3 and 0.5 as mild and above these values as strong (Holmes-Smith, 2000). From Table 2 below it can be seen that most regression weights are mild to strong and above 0.3 . Those below 0.3 include the path WF1W $\leftarrow$ work_aspects which suggests that this is not regarded as a work related feature but as a soft skill. Squared multiple correlations presented in Table 3 are generally above the recommended minimum value of 0.3 suggested for good item reliability (Holmes-Smith, 2000).

\section{Squared Multiple Correlations}

\begin{tabular}{|l|c|c|c|c|}
\hline Variable & Students & Academics & $\begin{array}{c}\text { IS } \\
\text { Practitioner }\end{array}$ & $\begin{array}{c}\text { IS Decision } \\
\text { Makers }\end{array}$ \\
\hline work_aspects & 0.41 & 0.32 & 0.17 & 0.37 \\
non-IS ed & 0.87 & 0.57 & 0.93 & 0.51 \\
IS ed & 0.71 & 0.67 & 0.10 & 0.50 \\
soft skills & 0.80 & 0.67 & 0.73 & 0.58 \\
OAF1W & 0.24 & 0.23 & 0.18 & 0.39 \\
F1W & 0.41 & 0.41 & 0.42 & 0.49 \\
F2W & 0.28 & 0.29 & 0.44 & 0.41 \\
F3W & 0.31 & 0.45 & 0.49 & 0.53 \\
OAF2W & 0.40 & 0.36 & 0.32 & 0.60 \\
SF2W & 0.38 & 0.31 & 0.37 & 0.29 \\
SF1W & 0.51 & 0.43 & 0.58 & 0.39 \\
WF1W & 0.38 & 0.19 & 0.30 & 0.24 \\
WF2W & 0.70 & 0.71 & 0.56 & 0.96 \\
\hline
\end{tabular}

Table 3: Squared Multiple Correlation Values $\left(\mathrm{R}^{2}\right)$ 
As a further indicator of model acceptability, standardized residual covariance values between indicators are each below the critical value of 2.58 as suggested by Hair, Anderson et al, (1998) and are significant at the 0.05 level.

IS practitioners appear to place a low emphasis on the value of IS education with the regression weight IS Professional->IS Ed being quite low and the $\mathrm{R}^{2}$ value indicating a very low explained variance.

Most of the $\mathrm{R}^{2}$ values were similar for most groups, with some interesting exceptions. The work_aspects factor is of similar importance to all groups except IS Professionals. Similarly, all groups except IS Professionals place similar value on non-IS education. All groups except IS Decision Makers place a relatively low value on OAF1W, non-IS academic subjects. IS Decision Makers place a much higher value on OAF2W, outwardly focused non-IS subjects which are those most directly connected with soft skills development.

Not surprisingly, all groups place a high value on F1W, high level application IS Academic Subjects. Students and academics place a somewhat lower value on $\mathrm{F} 2 \mathrm{~W}$, design and development IS Academic Subjects. Web related subjects, $\mathrm{F} 3 \mathrm{~W}$, are also highly rated by all groups.

All groups place high value on work related factors, WF2W, resulting in the highest $R^{2}$ values across the table. The high value $\left(R^{2}=0.96\right)$ from the IS Decision Makers group suggests that they view components such as salary, company shares, company cars, and other hygiene factors as of paramount importance to a greater degree than do the other groups of stakeholders.

\section{DISCUSSION}

Most research published in the area of skills is based on one view of the IS professional. A number of studies have been published on technical skills required as perceived by the various stakeholders or comparing the perceptions of stakeholders. There is also a body of work illustrating the growing importance of soft skills, again from the perspective of various stakeholders. A number of studies have also been published concerning the effects of the working environment on IS professional perceptions of their work situation. Another body of work has been presented illustrating the importance placed on business related skills acquired as part of the IS graduate's preparation.

To the authors' knowledge, no research has appeared which links these areas together in a dynamic structural model. The research reported in this paper addresses this issue. The findings suggest that there is a stable and interactive relationship between these four factors. The model shows the 
relative importance and strength of the factors. Development of a structural model advances our knowledge of the constellation of skills, knowledge, and values held by IS stakeholders beyond conventional factor analysis which does not allow for comparison of the significance of these factors. For the first time it is possible to show the interacting relationships of the four factors along with measures that suggest their relative importance to each of the stakeholder groups.

The model shows a good fit for all four sets stakeholder data. An important requirement for any model is that it is able to fit to independent sets of data, a requirement satisfied in this case.

The results presented here indicate that the perceptions of four stakeholder groups can be described by a second order, four latent factor model described in terms of hard IS skills, non-IS educational skills, personal attributes and soft skills and the job conditions.

It should be stressed that the model is not necessarily the only one that can fit the data. It does however show that it is possible to develop a comprehensive model to explain the various attributes of the IS professional. Ultimately it is hoped that such a model can be useful in improving the career prospects of new graduates and as providing indicators of shifting emphasis and value of these factors as individuals change stakeholder groups as their careers develop.

\section{REFERENCES}

ACM-AIS "IS 2002 - Model Curricula and Guidelines for Undergraduate Degree Programs in Information Systems," New York, (Accessed 7 January 2004), 2002. Available at: http://www.acm.org/education/curricula.html $\$ 1 S 2002$.

Ashley, N.W. and Padgett, T.C. "Information Systems Graduates: Evaluation of Their IS Curricula," (Accessed 7 January 2004), 1997. Available at: http:/www. westga.edu/ bquest/1998/infosys.html

Beachboard, J.C., and Parker, K.R. "How Much is Enough? Teaching Information Technology in a Business-Oriented IS Curriculum," Ninth Americas Conference on Information Systems, AIS, Tampa, FA, 2003, pp. 3026-3031.

Cappel, J.J. "Entry-Level IS Job Skills: A Survey of Employers," Journal of Computer Information Systems (42:2, Winter) 2001/2002, pp 76-82.

Cheney, P.H. "Information System Skill Requirements: 1980 \& 1990," ACM:4) 1988.

Cronbach, L.J. "Coefficient Alpha and the Internal Consistency of Tests," Psychometrika (16), 1951, pp. 297-334.

Davis, G.B., Gorgone, J.T., Couger, J.D., Feinstein, D.L., and Longenecker, J., H.E. (Eds) "IS'97 Model Curriculum and Guidelines for Undergraduate Degree Programs in Information Systems," The Data Base for Advances in Information Systems (28:1) 1997. 
Doke, E.R., and Williams, S.R. "Knowledge and Skill Requirements for Information Systems Professionals: An Exploratory Study," Journal of IS Education (10:1 (Spring)) 1999, pp 10-18.

Farwell, D., Lee, D.M., and Trauth, E.M. "Critical Skills and Knowledge Requirements of IS Professionals: A Joint Academic/Industry Investigation," MIS Quarterly) 1995, pp 313337.

Farwell, D., Lee, D.M., and Trauth, E.M. "The IS expectation gap: Industry expectations versus academic preparation," MIS Quarterly (17) 1993, p 293.

Gorgone, J. T., D. L. Feinstein, et al. (2002). Undergraduate Information Systems Model Curriculum Update - IS 2002. Eighth Americas Conference on Information Systems.

Goles, T. "A View from the Entry Level: Student Perceptions of Critical Information Systems Job Attributes." SIGCPR 2001, San Diego CA, 2001, pp. 57-64.

Hair, J.F., Anderson, R.E., Tatham, R.L., and Black, W.C. Multivariate Data Analysis, (5th ed.) Prentice-Hall, Upper Saddle River, NJ, 1998.

Holmes-Smith, P. "Introduction to Structural Equation Modelling," ACSPRI 2000, 2000, p. 143.

Lee, S., Koh, S., Yen, D. and Tang, H.-L. "Perception Gaps Between IS Academics and IS Practitioners: An Exploratory Study," Information and Management (40(1):October), 2002, pp. 51-61.

Leitheiser, R.L. "MIS Skills for the 1990s: A Survey of MIS Managers' Perceptions," Journal of Management Information Systems (9:1, Summer) 1992, pp 69-91.

Leonard, L. "Survey Shows Skills Gap Still a Problem," 1999. Available on-line at $<$ http://www.itac.cal $>$ Accessed 23/6/2002

Litecky, C., and Arnett, K. "An Update on Measurement of IT Job Skills for Managers and Professionals," Seventh Americas Conference on Information Systems, 2001, pp. 19221924.

Little, J.C., Granger, M.J., Boyle, R., Gerhardt-Powals, J., Impagliazzo, J., Janik, C., Kubilis, N.J., Lippert, S.K., McCracken, W.M., Paliwoda, G., and Soja, P. "Integrating Professionalism and Workplace Issues into the Computing and Information Technology Curriculum," ITiCSE '99 Working Group Reports (33:4) 1999, pp 106-112.

Orr, J., and von Hellens, L. "Skill Requirements of IT\&T Professionals and Graduates: An Australian Study," ACM SIGCPR, Chicago, 2000, pp. 167-170.

Ross, J., and Ruhleder, K. "Preparing IS Professionals for a Rapidly Changing World: The Challenge for IS Educators," Special Interest Group on Computer Personnel Research Annual Conference, St Louis MO, 1993, pp. 379-384.

Schumacker, R.E., and Lomax, R.G. A Beginners Guide to Structural Equation Modelling Lawrence Erlbaum Associates, Mahwah, New Jersey, 2004, p. 288.

Snoke, R., and Underwood, A. "Generic Attributes of IS Graduates - a Queensland Study," Proceedings of the Ninth Australasian Conference on Information Systems, Sydney NSW, 1998a, pp. 615-623.

Snoke, R., and Underwood, A. "Generic Attributes of IS Graduates - an Australian Study," Sixth European Conference on Information Systems, Granada: Euro-Arab Management School, Aix-en-Provence, 1998b, pp. 1713-1720.

Tang, H.-L., Lee, S., and Koh, S. "Educational Gaps As Perceived By Is Educators: A Survey Of Knowledge And Skill Requirements." Journal of Computer Information Systems (41:2) Winter 2001, pp 76-84.

Trauth, E., Farwell, D., and Lee, D. "The IS Expectation Gap: Industry Expectations Versus Academic Preparation," MIS Quarterly (17:3 (September)) 1993, pp 293-307. 
Turner, R., Fisher, J., and Lowry, G. (2004). Describing the IS Professional with a Structural Model. PACIS 2004 Conference, Shanghai, China.

Turner, R., and Lowry, G. "The Compleat Graduate: What Students Think Employers Want and What Employers Say They Want in New Graduates," Sixteenth Pan-Pacific Business Conference, Pan-Pacific Business Association, Nadi, Fiji, 1999, pp. 272-274.

Turner, R., and Lowry, G. "The Third Dimension of the IS Curriculum: The Importance of Soft Skills for IT Practitioners." ACIS 2001, Coffs Harbour, NSW, Australia, 2001, pp. 683-686.

Underwood, A. "The ACS Core Body of Knowledge for Information Technology Professionals," 1997. On-line at <http://www.acs.org.au/national/pospaper/bokpt1.htm> Accessed 21/7/2000

Van Slyke, C., Kittner, M., and Cheney, P. "Skill Requirements for Entry-Level IS Graduates: A Preliminary Report from Industry," 1997. Available on-line at <http://groucho.bsn. usf.edu/ vanslyke/isecon_1.htm> Accessed 26/4/2000

Williams, P.A. (1998). "Employability Skills in the Undergraduate Business. Curriculum and Job Market Preparedness: Perceptions of Faculty and Final-Year Students in Five Tertiary Institutions..." Unpublished PhD Dissertation, Andrews University.

Wong, E.Y.W. "The Education and Training of Future Information Systems Professionals," Education + Training (38:1) 1996, pp 37-43.

Young, D. "The Relative Importance of Technical and Interpersonal Skills for New Information Systems Personnel." Journal of Computer Information Systems (37:Summer) 1996, pp 66-71.

Young, J. and Keen, C. "The Emergence Importance of Broader Skills and Personal Attributes in the Recruitment of Australian IS Professionals," In Eighth Australasian Conference on Information Systems, D. J. Sutton (Ed.), Australian Computer Society \& ACIS Executive, Adelaide, South Australia, 1997, pp. 682-692. 